\title{
ANALISIS PENDIDIKAN, PENGALAMAN KERJA DAN PELATIHAN PADA PELAYANAN APARATUR PAJAK DI UPTD SAMSAT AMURANG
}

\author{
Ryan T. Regah ${ }^{1}$, Harijanto Sabjino ${ }^{2}$, Sherly Pinatik ${ }^{3}$ \\ 1,2,3 Jurusan Akuntansi, Fakultas Ekonomi dan Bisnis, Universitas Sam Ratulangi, Jl. Kampus Bahu, Manado, \\ 95115, Indonesia \\ E-mail : Ryanregah3616@gmail.com
}

\begin{abstract}
In essence, the main task of the government as a public organization is to provide services to the community. Likewise with SAMSAT Amurang as one of the public organizations that are directly related to public services. SAMSAT has the duty to serve the community in terms of managing payments for Motor Vehicle Taxes (PKB) and Taxes on Transfer of Motor Vehicles $(B B N K B)$. The tax sector is an important sector in national development, because most of the development is financed from $P K B$ and BBNKB sectors and then increase, one of hte factors is due to the increasing number of taxpayers who pay taxes. Every day SAMSAT serves hundreds of taxpayers. By increasing the number of these taxpayers can SAMSAT withdraw taxes which in turn will be used for state financing. As one of its contributions SAMSAT strives to provide the best service in accordance with the expectations and needs of the community as taxpayers.
\end{abstract}

Keywords : Final Income Tax, Construction Services

\section{PENDAHULUAN}

Pengalaman kerja adalah proses mengklasifikasikan, melaporkan suatu transaksi perusahaan dalam suatu laporan keuangan. Pengalaman kerja adalah ukuran tentang jangka waktu seseorang dalam melakukan pekerjaab. Tidak cuma itu ada juga beberapa faktor yang sangat mempengaruhi pekerjaan. Ada faktor-faktor yang mempengaruhi kondisi perusahaan akan tetapi adalah tidak mungkin untuk menyatakan secara tepat semua faktor yang dicari dalam penilaian dan penganalisaan. Sedangkan pendidikan dengan perkembanan zaman sekarang telah berubah sehingga mengedepankan pola pikir yang modern dikalangan masyarakat saat ini.Sehingga berpengaruh terhadap kemajuan pendidikan di Indonesia khususnya sulut. Kemudian para pakar pendidikan menyikapi bahwa pendidikan yang sesungguhnya ketika boleh berbagi dengan orang di sekitar kita, merupakan pendidikan yang sesungguhnya.

Seseorang yang berkualitas dan berkarakter merupakan suatu tujuan dari pendidikan, sehingga memiliki pandangan yang luas kedepan untuk mencapai suatu cita- cita yang ketika masuk dalam lingkugan boleh melahirkan para pelajar-pelajar yang berkualitas dan berkompeten. Di Negara Indonesia pajak merupakan unsur utama dalam hak pembayaran masyarakat kepada pemerintah. Pemerintah berupaya dalam perbaikan dan penyempurnaan pajak-pajak yang ada di negara ini. Reformasi pajak merupakan perubahan-perubahan peraturan perpajakan dalam kondisi tertentu. Reformasi pajak dilakukan untuk mengingatkan masyarakat tentang pembayaran pajak. Akan tetapi, banyak warga Negara yang masih menganggap pajak sebagai suatu beban.. Pelatihan adalah proses kemampuan sesorang untuk meningkatkan tugas tanggung jawab dalam pekerjaan. (Rasyid 2013) Pemberian pelatihan yang memenuhi standar yang telah ditetapkan memang menjadi bagian yang perlu dicermati. Untuk saat ini masih sering dirasakan bahwa kualitas pelatihan minimum sekalipun masih jauh dari yang diharapkan oleh masyarakat. Yang lebih memprihatinkan lagi, masyarakat hampir sama sekali tidak memahami secara pasti tentang pelayanan yang seharusnya diterima 
dan sesuai dengan pelayanan yang baku oleh Pemerintah. Pemerintah sebagai service provider (penyedia jasa) bagi masyarakat dituntut untuk memberikan pelayanan yang baik. Hal ini dikarenakan birokrasi mempunyai peranan yang sangat besar dalam kehidupan masyarakat terutama dalam memberikan pelayanan. Berdasarkan hasil observasi awal, masih banyak masyarakat yang kurang puas dengan pelayanan yang diberikan oleh pegawai yang ada di Kantor Samsat tersebut.

\section{TINJAUAN PUSTAKA}

Akuntansi. Akuntansi adalah proses pelaporan suatu perusahaan tentang laporan keuangan atau proses mengidentifikasi keuangan negara atau ilmu mengklasifikasikan, melaporkan kegiatan transaksi keuangan dalam suatu laporan keuangan dalam perusahaan untuk pengambilan keputusan.

Principal Accounting. Akuntansi adalah kegiatan jasa yang berfungsi menyediakan informasi kuantitatif terutama yang bersifat keuangan yang kemudian dapat digunakan untuk pengambilan keputusan atau sekumpulan prinsip, standar dan prosedur akuntansi yang harus dipatuhi oleh perusahaan dalam menyusun laporan keuangan (Madiarsmo 2016).

Intermediate Accounting. Ilmu ekonomi (khususnya akuntansi), yaitu akuntansi intermediate yang dapat didefinisikan sebagai akuntansi keuangan menengah.yaitu konsep dasar, Laporan keuangan, Proses Akuntansi, Langkah-langkah penyusunan laporang keuangan, Kas dan Investasi, Penanamaan modal dalam obligasi, Aktiva tetap berwujud depresiasi dan penilaian kembali, Perubahan metode akuntansi dan koreksi kesalahan (Sari Diana 2014).

Akuntansi Pajak. Menurut Sukrisno Agoes (2014) menjelaskan akuntansi pajak sebagai berikut : Akuntansi yang diterapkan sesuai dengan peraturan perpajakan disebut akuntansi pajak. Akuntansi pajak merupakan bagian dari akuntansi komersial yang diatur dalam Standar Akuntansi Keuangan (SAK). Proses laporan keuangan berdasarkan undangundang perpajakan.

Pendidikan. Menurut Saud Husnan (2013) "Pendidikan adalah suatu kegiatan untuk meningkatkan pengetahuan umum seseorang termasuk didalamnya peningkatan penguasaan teori dan keterampilan memutuskan terhadap persoalan-persoalan yang menyangkut kegiatan untuk mencapai tujuan". Pendidikan adalah pembelajaran pengetahuan, keterampilan, dan kebiasaan sekelompok orang yang diturunkan dari satu generasi ke generasi berikutnya melalui pengajaran, pelatihan, atau penelitian.

Pendidikan (ALFABETA). Pendidikan yang diberikan untuk mengembangkan berbagai macam metode seperti, pengembangan spiritual, mental, berakhlak, pengendalian diri. Dan ini berpengaruh terhadap proses pekerjaan yang akan ditempuh bagi mereka yang sudah melamar pekerjaan di suatu perusahaan.

Pendidikan menurut UU No 20 Tahun 2003. Secara umum adalah usaha dari dalam diri sendiri bahwa pendidikan merupakan suatu proses pembudayaan dan pemberdayaan peserta didik yang berlangsung sepanjang hayat dengan memberi keteladanan dalam pengendalian mutu layanan pendidikan.

Pengalaman Kerja. Pengalaman kerja adalah proses pembentukan pengetahuan karyawan dalam melaksanakan suatu tugas tertentu (Depdiknas 2013). Di dunia kerja orang yang berpengalaman dalam bekerja memiliki kemampuan kerja yang lebih baik dari orang yang baru saja memasuki dunia kerja, karena mereka telah belajar dari permasalahan atau telah lebih dulu masuk dalam dunia perkerjaan. Dengan adanya pengalaman kerja maka ada penambahan ilmu pengetahuan dan keterampilan dapat menunjang pengembangan diri aparatur pajak serta keterampilan dalam melakukan pelayanan. Hubungan antara stimulus dan respon akan bertambah kuat atau erat bila sering digunakan (use) atau sering dilatih (exercise) dan akan berkurang, bahkan lenyap sama sekali jika jarang digunakan atau tidak 
pernah sama sekal. Karyawan memerlukan pelatihan untuk menunjang kinerja pelayanan, sehingga pekerjaan terlaksana dengan begitu baik. Fasilitas pelatihan juga harus menunjang dalam hal ini.

Peran Pengalaman Kerja Aparatur Pajak. Istilah peran digunakan dalam beberapa penilitian, khususnya di ilmu sosial. Menurut Taneko (2014) peran adalah kegiatan organisasi yang berkaitan dengan menjalankan tujuan untuk mencapai hasil yang ditetapkan. Berdasarkan pendapat pengalaman kerja aparatur berpengaruh terhadap kinerja pegawai samsat dalam melakukan proses pelayanan. Karena pentingnya pengalaman kerja dalam suatu perusahaan maka ada beberapa faktor dalam pengalaman kerja:

1. Waktu. Seseorang yang melakukan pekerjaan dengan jangka waktu yang lama memiliki bekal yang lebih baik dalam pengalaman kerja di perusahaan.

2. Sikap. Pentingnya pengalaman kerja bisa dilihat dari sikap aparatur pajak dalam melakukan pekerjaan, yang dibutuhkan adalah sikap jujur serta bertanggung jawab.

3. Jenis tugas. Semakin banyak jenis tugas yang dilaksanakan oleh seseorang maka umunya orang tersebut akan memperoleh pengalaman kerja yang lebih banyak.

Pengalaman Kerja. Elaine Johnson (2014) Potensi akan terlihat dari diri kita sendiri ketika melakukan suatu pekerjaan dan menikmati pekerjaan tersebut. Jadi sesungguhnya yang penting diperhatikan dalam hubungan tersebut adalah kemampuan seseorang untuk belajar dari pengalamannya, kemampuan ini nanti diperlukan ketikan masuk dalam dunia pekerjaan dimana sangat berperan penting dalam melakukan tugas tanggung jawab ketika mempunyai pengalaman kerja yang baik.

Pelatihan. Pelatihan adalah suatu kegiatan untuk mencapai kemampuan kerja seseorang dalam kaitannya dengan kegiatan ekonomi. Pelatihan membantu karyawan dalam memahami suatau pengetahuan praktis dan penerapannya, guna meningkatkan keterampilan, kecakapan dan sikap yang diperlukan oleh organisasi guna mencapai tujuan. Menurut Edwin B. Flippo (2015) "Pelatihan berhubungan dengan penambahan pengetahuan dan kecakapan untuk melaksanakan suatu jenis pekerjaan tertentu yang mana sangat tergantung dari suatu organisasi perusahaan didalam mana jenis pekerjaan itu terdapat pendidikan berhubungan dengan penambahan pengetahuan dan pengertian yang didapat dari lingkungan sekolah yang formal". Pendidikan merupakan suatu kegiatan untuk menambah wawasan secara luas untuk mencapai suatu tujuan karena pendidikan dan pelatihan bersifat sangat luas. Berikut adalah beberapa tujuan dari pendidikan dan pelatihan :

1. Agar memiliki wawasan dalam melakukan pekerjaan dan menyelesaikan tugas dengan baik.

2. Kualitas pekerjaan berjalan dengan baik dengan pelatihan yang sudah dilakukan.

3. Untuk mengubah perilaku egois dan memiliki karakter ingin bekerja sama dengan orang lain.

\section{Macam-Macam Pelatihan}

Produktivitas. Sumber daya pendidikan dan pelatihan diatur dan dimanfaatkan. Hal ini dapat meningkatkan prestasi kerja karyawan yang akhirnya juga akan mencapai tujuan perusahaan.

Kualitas. Pendidikan dan pelatihan yang dirancang dan dilaksanakan dengan baik akan menolong karyawan untuk memproduksi hasil yang lebih tinggi kualitasnya (mutunya) guna mencapai tujuan perusahaan.

Perencanaan Sumber Daya Manusia. Sumber daya manusia yang baik berpengaruh terhadap kualitas kerja karyawan sehingga memaksimalkan pekerjaan karena sehingga harus direncanakan dengan baik.

Moral. Meningkatkan moral karena sangat berpengaruh untuk peningkatan produktivitas kerja dan berdampak pada pendidikan dan pelatihan. 
Kompensasi Tidak Langsung. Dalam kompensasi juga termasuk insentif dan program kesejahteraan karyawan merupakan hal yang sangat penting.

Kesehatan dan Keselamatan. Mental dan kesehatan fisik dari aparatur pajak berpengaruh sehingga dihubungkan pada pelayanan dan pendidikan. Karena pendidikan dan pelatihan juga mengutamakan keselamatan kerja dalam melaksanakan tugas dan tanggung jawab.

Mencegah Keausan. Program pendidikan dan pelatihan jangan hanya bersifat monoton saja, harus bersifat kreatif sehingga mencegah kausan yang ada.

Pertumbuhan Pribadi. Pendidikan dan pelatihan bermanfaat bagi perusahaan terutama secara individu/pribadi guna mengembangkan apa yang sudah diberikan untuk perusahaan dan mencapai tujuan bersama.

\section{Macam macam Pelayanan Publik}

Sederhana. Sederhana yang artinya mudah dimengerti merupakan hal utama dalam suatu pelayanan di perusahaan. Seluruh pelayanan yang ada di Kantor SAMSAT Kabupaten Minsel umumnya telah berjalan dengan baik tetapi kendala yang masih banyak di bicarakan mengenai sarana prasarana perusahaan di Kantor SAMSAT Kabupaten Minsel. Beberapa pendapat yaitu fasilitas umum yang ada di kantor masih banyak yang kurang untuk kebutuhan pelayanan. Kantor SAMSAT Kabupaten Minsel telah memenuhi prinsip sederhana, khususnya dalam pelayanan publik dimana pelayanan pembayaran diakui sebagai pelayanan yang berkualitas, Sehingga membantu masyarakat dalam proses pembayaran di perusahaan dan menciptakan kepuasan. Saat ini belum ada keluhan dari masyarakat tentang pelayanan yang ada di SAMSAT Amurang.

Konsistensi. Ketetapan persyaratan, prosedur, dan biaya merupakan bagian dari pelayanan publik yang diberikan, diproses secara mudah untuk menjangkau masyarakat yang sesuai dengan standar prosedur yang sudah diberikan. Pelayanan harus dipertanggung jawabkan karena sudah ditetapkan semestinya. Menjaminkan konsistensi persyaratan, serta melaksanakan pelayanan kepada wajib pajak sesuai ketetapan. Pendapat yang muncul dari masyarakat mengenai efektivitas waktu pelayanan, ketepatan waktu pelayanan, keterjangkauan memberikan pelayanan, serta kesopanan petugas pelayanan. Adapun hasil kesimpulan tersebut dapat ditarik mengenai prinsip konsistensi dalam pelayanan publik yang ada di Kantor SAMSAT Kabupaten Minsel sudah terlaksana dengan baik atau telah diuji prosedur pelayanan dengan hasil meuaskan dari ketetapan karakter dari setiap pelayanan di Kantor SAMSAT Kabupaten Minsel.Karena ini semua berpengaruh terhadap kepuasan masyarakat di SAMSAT tentunya yang diharapkan mereka bahwa adanya konsistensi dari perusahaan yang membuat pelanggan disini merasa nyaman.

Partisipatif. Dalam prinsip partisipatif yaitu standar pelayanan dengan melibatkan masyarakat untuk membahas keselarasan atas dasar komitmen. Kantor SAMSAT Kabupaten Minsel. ketersediaan sistem pengaduan, mekanisme complain merupakan bagian dari prinsip partisipatif pelayanan publik, penelitian yang dilakukan ini meliputi pelayanan dalam pemberian saran maupun keluhan dari masyarakat, pelayanan publik, dan produktifitas.. Hasil yang didapat pada masyarakat setelah wawancara adalah prinsip partisipatif yang masih kurang komunikasi untuk penggunaan fasilitas pengaduan pelayanan di Kantor SAMSAT Kabupaten Minsel. Masyarakat atau individu masyarakat adalah objek pelayanan yang diselenggarakan penyelenggara Negara. Sehingga untuk berpartisipasi, masyarakat harus menjadi pengguna layanan yang berintegritas, peka dan kritis.

Akuntabel. Akuntabel yang dimaksud disini adalah standar pelayanan harus dilakukan dan dipertanggung jawabkan dengan baik tanpa merusak nilai-nilai yang terkandung. di Kantor SAMSAT Kabupaten Minsel dalam penelitian ini, meliputi tingkat kesesuaian pelayanan dengan harapan masyarakat dan kepuasan wajib pajak. Tingkat kualitas pelayanan publik berpengaruh terhadap tingkat kepuasan masyarakat, semakin tinggi tingkat 
kualitas pelayanan publik yang diberikan maka akan semakin tinggi pula tingkat kepuasan masyarakat (wajib pajak). Dari hasil wawancara dengan masyarakat mengenai prinsip akuntabel yaitu pelayanan pembayaran BBNKB dan PKB di Kantor SAMSAT Kabupaten Minsel sudah sudah selayaknya dikatakan memuaskan. Hal ini berarti bahwa pelayanan telah mencapai tujuan secara prima kepada para wajib pajak.Standar pelayanan publik harusdapat dipertanggungjawabkan secara terbuka, baik kepada publik maupun kepada atasan atau pimpinan unit instansi perusahaan atau unit pelayanan instansi pemerintah.

Berkesinambungan. Artinya berkesinambungan mengikuti teknologi yang ada, sebelumnya SAMSAT Amurang memiliki teknologi yang kurang memadai tetapi sekarang sudah dilengkapi berbagai fasilitas. Perubahan harus menyatukan masyarakat dengan lingkungan sekitar. Yang berkaitan dengan prinsip berkesinambungan dalam pelayanan publik adalah pendapat masyarakat mengenai ada tidaknya perubahan perubahan pelayanan di Kantor SAMSAT Kabupaten Minsel..agar pelayanan ini dapat berlanjut demi kesejahteraan masyarakat dalam melakukan pelayanan, perkembangan perusahaan SAMSAT Amurang begitu pesat sehingga dilihat fasilitas umum teknologi yang sudah maju membantu jalannya proses pembayaran dengan baik mendengar hal tersebut kepala bidang pelayanan SAMSAT sendiri ingin menambah fasilitas ruang kerja yang memadai serta untuk perogram pelatihan SAMSAT.

Transparansi. Masyarakat harus mengetahui semua kondisi yang ada di kantor SAMSAT baik kondisi internal maupun eksternal perusahaan. Mencakup prosdur pelayanan, waktu pelayanan, tempat pelayanan,. Beberapa pertanyaan masyarakat mengenai prinsip transparansi dalam pelayanan publik di Kantor SAMSAT Kabupaten Minsel adalah yaitu ketersediaan sarana prasarana, serta informasi dalam proses pembayaran di Kantor SAMSAT Kabupaten Minsel. Seluruh akses dapat diakses dengan mudah oleh masyarakat sekarang, dan jika informasi yang diberikan kurang bisa tanya langsung oleh yang bersangkutan di Kantor SAMSAT Kabupaten Minsel. Transparansi, meningkatkan kepercayaan yang timbal balik antara pemerintah dan masyrakat melalui penyediaan informasi dan menjamin kemudahan dalam memperolah informasi yang akurat dan memadai, transparansi harus dibangun dalam rangka kebebasan aliran informasi. Informasi harus dapat dipahami dan dapat dimonitor dengan baik.

Keadilan. Pelayanan yang diberikan bersifat merata terhadap masyarakat karena mereka memilik kesulitan soal jarak lokasi geografis, dan perbedaan kapabilitas fisik dan mental, dalam artian pelayanan yang dilakukan harus nyaman tanpa ada kendala dari masyarakat sendiri. Sehingga masyarakat mendapat pelayanan yang sama tanpa ada memandang faktor ekonomi, maupun jarak lokasi, Karena ini yang selalu ditekankan dalam bidang pelayanan bahwa keadilan dalam pelayanan merupakan yang utama. Keadilan mempertanyakan distnibusi dan alokasi layanan yang diselenggarakan oleh organisasi pelayanan publik. Kriteria ini erat kaitannya dengan konsep ketercukupan atau kepantasan. Soal keadilan dalam perushaan ini mencakup yang utama sehingga masyarakat yang memilki kesulitan dibantu dengan mudah oleh aparatur pajak yang berwenang.

\section{METODE PENELITIAN}

Jenis Penelitian. Jenis penilitian sesuai wawancara yang diambil bersifat deskriptif dan nyata sehingga memudahkan pelajar mendapatkan informasi yang ada . (Bogdan dan Taylor, dalam Sujarweni 2015). Dalam hal ini mendeskripsikan tentang bagaimana analisis pendidikan, pengalaman kerja, dan pelatihan aparatur pajak dalam melakukan pelayanan di SAMSAT Amurang ini.

Tempat dan Waktu Penilitian. Lokasi penelitian dilaksanakan di Amurang yakni UPTD Samsat Amurang Waktu penelitian dilaksanakan pada bulan Maret sampai Agustus 2018.

\section{Jenis Data}


Data Kualitatif. Data kualitatif dimana penilitian ini berupa hasil wawancara langsung dengan bagian seksi pelayanan PKB dan BBNKB di UPTD Samsat Amurang.

Data Kuantitatif. Data Kuantitatif berupa laporang pertanggungjawaban dalam bentuk laporan target dan aktual di kantor Samsat Amurang atau jenis data yang dapat diukur atau dihitung secara langsung.

Sumber Data. Sumber data di dalam penilitian ini adalah data primer menurut Istijanto (2015) data primer adalah data asli yang dikumpulkan sendiri oleh peniliti untuk menjawab masalah penilitiannya secara khusus. Sumber data primer dalam penilitian ini adalah diperoleh dari bidang pelayanan yang ada di Samsat Amurang.

Metode dan proses analisis. Metode yang digunakan dalam penilitian ini yaitu metode deskriptif dimana data-data yang diperlukan dalam penilitian ini diperlukan proses analisa yang tepat sehingga mengambil data-data yang tepat dan akurat dari perusahaan. Adapun proses-proses analisa yang dilakukan dalam penilitian ini:

1. Pengumpulan data, yaiut peneliti mencatat semua data secara objektif dan apa adanya sesuai dengan proses wawancara yang dilakukan.

2. Menganalisa data, yaitu peniliti menganalis data-data yang didapat melalui wawancara dan dokumentasi di tempat penilitian.

3. Penyajian data, data yang disajikan dalam penilitian ini adalah hasil wawancara dengan responden yang akan disusun secara sistematis.

4. Pemberian kesimpulan dan saran, setelah data disajikan maka dilakukan pemberian kesimpulan dan saran.

\section{HASIL PENELITIAN DAN PEMBAHASAN}

\subsection{Hasil Penelitian}

Deskripsi data penelitian. Pelayanan Pajak Kendaraan Bermotor di SAMSAT Amurang Permasalahan pada kualitas pelayanan masih sering dijumpai dibeberapa instansi pemerintah. Pada umumnya semua instansi memiliki masalah dalam pelayanan, pelayanan yang beragam, baik di tingkat pusat maupun di tingkat bawah yang berhadapan langsung dengan masyarakat mengalami banyak hambatan dan belum sepenuhnya terwujud pelayanan prima seperti yang diharapkan. Berdasarkan data realisasi pendapatan pajak di Amurang, dari tahun ke tahun pajak dari kendaraan bermotor menduduki peringkat pertama. Pajak kendaraan bermotor menjadi andalan bagi pembangunan. Apabila melihat kontribusi pendapatan dari pajak kendaraan bermotor yang paling besar diantara pajak-pajak yang lain, maka pelayanan pajak kendaraan bermotor yang prima diseluruh kantor SAMSAT Amurang harusnya menjadi prioritas utama bagi pemerintah dalam mendorong peningkatan kualitas layanan bagi masyarakat. Dalam pengadaan pelayanan di Samsat perusahaan mengutamakan mutu pendidikan agar pelayanan berjalan dengan efektif agar dapat memberikan pelayanan dengan sebaikbaiknya dan terus berupaya meningkatkan pelayanan yang berkualitas. Standar pelayanan tersebut adalah:

1. Pelayanan secara berintegritas serta karakter yang sopan, jujur dan bertanggung jawab menjadi hal utama dalam perusahaan.

2. Proses pelayanan dilakukan dengan waktu yang efektif.

3. Setiap petugas berupaya meningkatkan ilmu pengetahuan, pendidikan, dan integritas.

4. Memahami karakter masyarakat secara tepat akurat sehingga mereka merasa nyaman dalam hal pelayanan.

Tingkat pendidikan aparatur pajak SAMSAT Amurang. Pendidikan merupakan suatu kegiatan peningkatan seseorang dalam penguasaan teori dan keterampilan. Kualitas pendidikan membantu aparatur pajak dalam melakukan pelayanan yang maksimal. Aparatur pajak samsat memiliki tingkat pendidikan yang berbeda, Mereka telah mencapai sarjana untuk tingkat pendidikan sisanya hanya lulusan SMA, dan mereka yang mencapai lulusan 
sarjana kebanyakan di tempatkan di bidang administrasi dan pelayanan sedangkan yang lulus SMA biasanya di bidang loket. Untuk itu manager samsat mengemukakan bahwa tingkat pendidikan di samsat ini cukup memenuhi syarat sehingga proses pelayanan yang di capai masih sangat bagus.

Pengalaman kerja aparatur pajak SAMSAT Amurang. Pengalaman kerja adalah keterlibatan karyawan dalam melaksanakan tugas dalam suatu perusahaan dengan melihat tingkat waktu yang di tempu selama perkerjaan. Sehingga bisa mempengaruhi pelayanan aparatur pajak, pengalaman kerja aparatur pajak disini ada dalam berbagai kondisi mereka yang sudah pernah bekerja di atas dua tahun memiliki kondisi analisa yang sangat baik dalam melakukan pelayanan sedangkan mereka yang masih minim pengalaman atau mereka yang masih bekerja di bawah dua tahun.

Pelatihan aparatur pajak SAMSAT Amurang. Pelatihan merupakan suatu kegiatan untuk menambah keterampilan aparatur untuk membentuk sikap dan mental dalam melakukan pekerjaan yang berkualitas. Samsat amurang melakukan pelatian seperti pembentukan mental, pengetahuan, juga menyediakan fasilitas untuk menunjang pelayanan aparatur pajak, dan saat ini samsat amurang telah melakukan pelatian dengan baik.

Kualitas Layanan. Dalam hal ini tidak lepas dari keterbukaan masyarakat dalam pelayanan yang harus dilakukan agar masyarakat tau tentang proses soal waktu serta besar kecilnya anggaran masyarakat dalam proses pembayaran STNK. Untuk melihat kualitas layanan juga harus dilihat dari sarana dan prasarana yang ada karena ketersediaan yang bagus membantu proses pelayanan dan dapat berjalan dengan baik dan membantu kualitas dalam pelayanan masyarakat, kenyamanan sangat diperlukan dalam proses pelayanan. SAMSAT Amurang menyediakan sarana prasarana dengan baik dan memudahkan masyarakat.

\subsection{Pembahasan}

Sesuai dengan konsep, pelayanan publik ialah suatu pemberian pelayanan prima kepada masyarakat yang merupakan perwujudan kewajiban pegawai pemerintah sebagai abdi masyarakat.. Begitu pentingnya profesionalitas pelayanan publik maka agar pelayanan menjadi lebih baik dan berkualitas perlu dilakukannya reformasi pelayanan publik yaitu melalui.Peraturan tersebut perlu dipedomani oleh setiap birokrasi publik dalam memberikan pelayanan kepada masyarakat berdasarkan prinsip-prinsip pelayanan. Pendidikan, Pengalaman Kerja, dan Pelatihan aparatur pajak menjadi faktor utama dalam proses pelayanan yang ada di samsat. Pendidikan aparatur pajak telah mencapai hasil yang baik yaitu Kualitas pendidikan membantu aparatur pajak dalam melakukan pelayanan yang maksimal.Pengalaman kerja mereka juga diuji oleh bidang pelayanan dimana ada yang sudah bekerja lebih dari dua tahun dan mengedepankan sikap profesional dalam bekerja. Pelatihan aparatur pajak dibekali keterampilan dan pengetahuan agar dapat menjalankan tugas sebaik-baiknya.

Tingkat Pendidikan. Kantor samsat telah melakukan pelayanan dengan baik karena pendidikan dari aparatur pajak berpengaruh terhadap kinerja mereka. Pendidikan karakter, kerajinan, kejujuruan menjadi yang utama dalam menunjang kinerja pegawai samsat. Pendidikan aparatur pajak telah mencapai hasil yang baik yaitu Kualitas pendidikan membantu aparatur pajak dalam melakukan pelayanan yang maksimal.

Tingkat Pengalaman Kerja. Pengalaman kerja aparatur pajak terbukti mampu menyelesaikan tugas dan tanggung jawab mereka, karena rata-rata dari mereka telah mengemban tugas lebih dari dua tahun dan ditempatkan di bidang mereka masing-masing. Serta masing-masing mempunyai kemahiran dalam melaksanakan tugas-tugas yang diberikan oleh pimpinan.

Tingkat Pelatihan. Pelatihan yang dilakukan sangat bermacam-macam, sarana-prasarana berpengaruh terhadap pelatihan aparatur pajak, Samsat amurang melakukan pelatian seperti 
pembentukan mental, pengetahuan, juga menyediakan fasilitas untuk menunjang pelayanan aparatur pajak, dan saat ini samsat amurang telah melakukan pelatian dengan baik.

\section{KESIMPULAN DAN SARAN}

\subsection{Kesimpulan}

Berdasarkan hasil penelitian ini dapat disimpulkan bahwa Kinerja Pegawai Samsat Dalam Pemberian Pelayanan Publik di Kantor Samsat Amurang adalah baik. Karena kantor SAMSAT ini mengutamakan pendidikan dibandingkan fasilitas untuk mengoptimalkan sumber daya manusia yang ada. Kualitas Kinerja Pegawai Samsat Dalam Pemberian Pelayanan Publik dari kriteria kinerja pegawai yaitu :

1. Diperlukan peningkatan kuantitas kinerja pegawai dengan cara pemberian insentif kepada para pegawai dengan tujuan agar pegawai lebih giat dan rajin bekerja dan menyelesaikan pekerjaan tepat pada waktunya.

2. Diperlukan pemberian sanksi atas keterlambatan pegawai, agar para pegawai bisa lebih bertanggung jawab dengan tugas dan pekerjaan yang diberikan.

3. Diperlukan perbaikan website dari Kantor Samsat Pusat dan perlu memperbanyak server data yang ada di Kantor Samsat.

\subsection{Saran}

Berdasarakan kesimpulan diatas diharapkan penilitian selanjutnya dapat menyajikan hasil penilitian yang berkualitas dengan adanya saran-saran mengenai beberapa hal:

1. Untuk penilitian selanjutnya SAMSAT harus memiliki fasilitas yang baik untuk menunjang kenyamanan masyarakat dalam melakukan proses pembayaran pajak.

2. Pendidikan merupakan faktor penting dalam pembentukan sumber daya manusia di SAMSAT ini.

3. Pengalamana kerja berpengaruh terhadap aparatur pajak dalam melayani masyarakat untuk itu harus ditingkatkan lagi

\section{DAFTAR PUSTAKA}

Agustin, Ayu 2010. Analisis Perbandingan Kepuasan Wajib Pajak Terhadap Kualitas Pelayanan Pembayaran Kendaraan Bermotor di Kantor samsat di Kabupaten Karanganyar Skripsi. Universitas Muhammadiyah. Surakarta

Aditya, Robby 2014. Analisis Kinerja Pelayanan Pada Samsat Daerah Surabaya Utara. Skripsi. Universitas Brawijaya

Ardiani, Leli. 2011. Implementasi Layanan Inovasi SAMSAT Keliling Dalam Upaya Meningkatkan Pelayanan Pembayaran Pajak- Pajak Kendaraan Bermotor Skripsi. Universitas Indonesia. Jakarta

Ahzar, Alwan. 2010. Analisis Penerapan Sistem Informasi Manajemen Dalam Mewujudkan Kualitas Pelayanan STNK Kantor Samsat di Samarinda Skripsi. Universits Gadjah Mada. Yogyakarta

Ahmad. 2010. Analisis Kepuasan Pelayanan Pajak Kendaraan Bermotor di Samsat Kota Semarang II.Skripsi. Universitas Maritim. Tanjung Pingan

Alwan 2010. Analisis Penerapan System Informasi Manajemen Dalam Mewujudkan Kualitas Pelayanan. Fakultas Ekonomi Program Studi Akuntansi- Universitas Komputer Indonesia

Andreas 2015. Analysis of he application of management information systems in realizing the quality of the samsat office service. Riau University, Indonesia

Andre De Quadros 2015. The influence of the quality of motorized vehicle tax services on community satisfaction. Yale University, America 
Bogdan dan Taylor. 2015. Metodologi Penelitian Kualitatif. Edisi Revisi. Bandung: PT. Remaja Rosdakarya

Depdiknas 2013. Pengertian pengalaman kerja. Bandung, PT Refika Aditama

Edwin Flippo. 2015. "Pelatihan” Edisi Revisi, Yogyakarta, Andi

Gabriel Bayu 2015. Pengaruh system informasi dalam proses pelayanan masyarakat. Program Studi Perpajakan- Universitas Brawijaya

Gaby Fransisca 2015. Pengaruh system samsat corner terhadap peningkatan pelayanan pembayaran kendaraan bermotor. Falkutas Ekonomi- Universitas Udayana Denpasar Bali.

Harispiandi.2005. Pengaruh kualitas pelayanan kendaraan bermotor terhadap kepuasan masyarakat.Falkutas Ekonomi Jurusan Akuntansi- Universitas Brawijaya

Hilman Akbar 2013 Analysis of motor vehicle tax service satisfaction in Samsat. Riau University, Indonesia

Istijanto.2015 pengertian data primer, data asli yang dikumpulkan sendiri oleh peniliti untuk menjawab masalah penilitiannya secara khusus. Skripsi. Universitas Gadjah Mada

Kartika Chandra 2013. Efforts to increase motor vehicle tax revenue to increase PAD Department of Accounting Faculty of Management. University of Benin, Nigeria

Kuncoro. 2013. Jenis Penilitian Kualitatif dan Kuantitatif. Edisi Revisi. Bandung: PT. Remaja Rosdakarya

Luciana Jayanti. 2014. Implementation of mobile samsat innovation services in an effort to improve motor vehicle tax payment services. Padjadjaran University- Bandung, Indonesia

Moleong, Lexy. 2005. Jenis Penilitian Kualitatif. Edisi Revisi. Bandung: PT. Remaja Rosdakarya

Novia, 2009. Analisis efektivitas pemungutan pajak. Skripsi. Universitas Gadjah Mada

Pohan, Chairil Anwar. 2011 Optimizing Corporate Tax Management. Jakarta: PT Bumi Askara.

Pohan, Chairil Anwar. 2013 Manajemen Perpajakan Strategi Perencanaan dan Bisnis. Jakarta: PT Gramedia Pustaka Utama.

Rochmat Soemitro, SH. 2011. Pajak Merupakan Iuran atau Pungutan Rakyat Kepada Pemerintah Dengan Berdasarkan Undang-Undang Yang Berlaku atau Peralihan Kekayaan Dari Sektor Swasta Kepada Sektor Publik Yang Dapat Untuk Dipaksakan Serta Yang Langsung Ditunjuk dan Dipakai Gunakan Untuk Membiaya Kebutuhan Negara. Yogyakarta

Salmon, Gita. 2015. Perhitungan dan Pencatatan Pajak Kendaraan Bermotor Roda Dua Pada Kantor Bersama Samsat Manado. Skripsi. Universitas Sam Ratulangi. Manado

Satriadi, 2017. Upaya peningkatan penerimaan pajak kendaraan bermotor untuk meningkatkan PAD. Skripsi, Yogyakarta : Falkutas Ekonomi- Universitas Yogyakarta

Saud Husnan, 2013. "Pendidikan". Edisi Revisi. Alfabeta

Undang-Undang Republik Indonesia Nomor 28 Tahun 2007 Pasal 1 Tentang kontribusi wajib kepada Negara yang terhutang oleh orang pribadi atau badan yang bersifat memaksa berdasarkan Undang-Undang. Jakarta

Undang-Undang nomor 25 tahun 2009 Tentang pelayanan publik, pelayanan publik adalah kegiatan atau rangkaian kegiatan dalam rangka pemenuhan kebutuhan pelayanan sesuai dengan peraturan perundang-undangan. Jakarta

Waluyo 2011. Perpajakan Indonesia. Jakarta Selatan: Salemba Empat 